Prepared in cooperation with the Harris-Galveston Subsidence District, City of Houston, Fort Bend Subsidence District, and Lone Star Groundwater Conservation District

\title{
Water-Level Altitudes 2011 and Water-Level Changes in the Chicot, Evangeline, and Jasper Aquifers and Compaction 1973-2010 in the Chicot and Evangeline Aquifers, Houston-Galveston Region, Texas
}

Scientific Investigations Map 3174 



\section{Water-Level Altitudes 2011 and Water- Level Changes in the Chicot, Evangeline, and Jasper Aquifers and Compaction 1973- 2010 in the Chicot and Evangeline Aquifers, Houston-Galveston Region, Texas}

By Michaela R. Johnson, Jason K. Ramage, and Mark C. Kasmarek

Prepared in cooperation with the Harris-Galveston Subsidence District,

City of Houston, Fort Bend Subsidence District, and Lone Star Groundwater Conservation District

Scientific Investigations Map 3174 


\title{
U.S. Department of the Interior \\ KEN SALAZAR, Secretary \\ U.S. Geological Survey \\ Marcia K. McNutt, Director
}

\section{U.S. Geological Survey, Reston, Virginia: 2011}

\author{
This and other USGS information products are available at http://store.usgs.gov/ \\ U.S. Geological Survey \\ Box 25286, Denver Federal Center \\ Denver, CO 80225 \\ To learn about the USGS and its information products visit http://www.usgs.gov/ \\ 1-888-ASK-USGS
}

\footnotetext{
Any use of trade, product, or firm names is for descriptive purposes only and does not imply endorsement by the U.S. Government.

Although this report is in the public domain, permission must be secured from the individual copyright owners to reproduce any copyrighted materials contained within this report.
}

Suggested citation:

Johnson, M.R., Ramage, J.K., and Kasmarek, M.C., 2011, Water-level altitudes 2011 and water-level changes in the Chicot, Evangeline, and Jasper aquifers and compaction 1973-2010 in the Chicot and Evangeline aquifers, HoustonGalveston region, Texas: U.S. Geological Survey Scientific Investigations Map 3174, 17 p., 16 sheets. 


\section{Acknowledgments}

The authors thank the owners and operators of wells throughout the study area for graciously granting access to wells and providing pertinent information. 



\section{Contents}

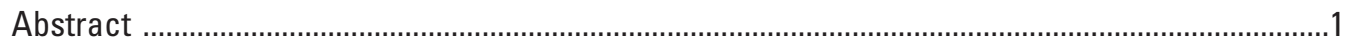

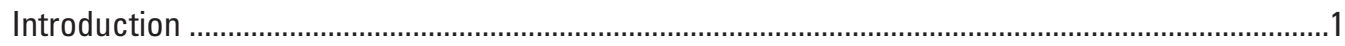

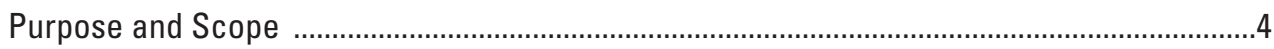

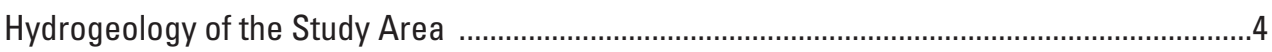

Subsidence and Compaction Processes .................................................................................

Data Collection and Analysis Methods ......................................................................................

Determination of Water-Level Altitudes ...............................................................................

Depicting Changes in Water-Level Altitudes ...................................................................

Borehole Extensometers .................................................................................................

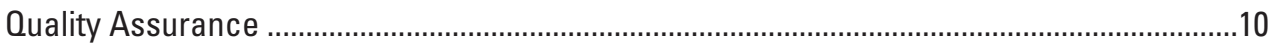

Water-Level Altitudes and Changes ......................................................................................

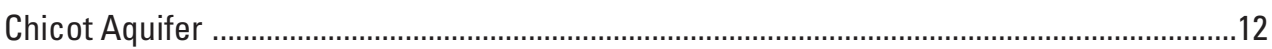

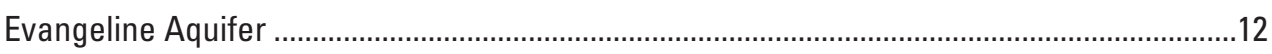

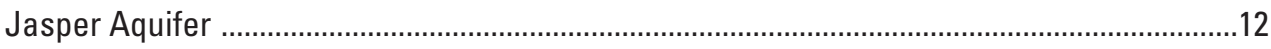

Compaction in the Chicot and Evangeline Aquifers ...................................................................

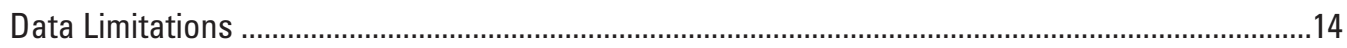

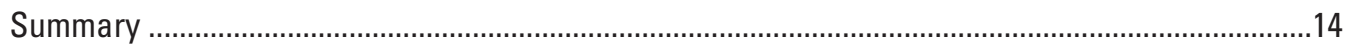

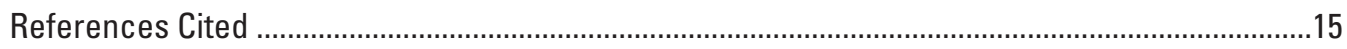

Appendix 1. Well location maps (available online at http://pubs.usgs.gov/sim/3174/)

1.1. Map showing location of wells screened in the Chicot aquifer, Houston-Galveston region, Texas.

1.2. Map showing location of wells screened in the Evangeline aquifer, Houston-Galveston region, Texas.

1.3. Map showing location of wells screened in the Jasper aquifer, Houston-Galveston region, Texas.

\section{Sheets}

(Available online at http://pubs.usgs.gov/sim/3174/)

1-15. Maps showing:

1. Approximate water-level altitudes in the Chicot aquifer, Houston-Galveston region, Texas, December 2010-February 2011.

2. Water-level changes in the Chicot aquifer, Houston-Galveston region, Texas, 2010-11.

3. Approximate water-level changes in the Chicot aquifer, Houston-Galveston region, Texas, 2006-11.

4. Approximate water-level changes in the Chicot aquifer, Houston-Galveston region, Texas, 1990-2011.

5. Approximate water-level changes in the Chicot aquifer, Houston-Galveston region, Texas, 1977-2011.

6. Approximate water-level altitudes in the Evangeline aquifer, Houston-Galveston region, Texas, December 2010-February 2011.

7. Water-level changes in the Evangeline aquifer, Houston-Galveston region, Texas, 2010-11. 
8. Approximate water-level changes in the Evangeline aquifer, Houston-Galveston region, Texas, 2006-11.

9. Approximate water-level changes in the Evangeline aquifer, Houston-Galveston region, Texas, 1990-2011.

10. Approximate water-level changes in the Evangeline aquifer, Houston-Galveston region, Texas, 1977-2011.

11. Approximate water-level altitudes in the Jasper aquifer, Houston-Galveston region, Texas, December 2010-February 2011.

12. Water-level changes in the Jasper aquifer, Houston-Galveston region, Texas, 2010-11.

13. Approximate water-level changes in the Jasper aquifer, Houston-Galveston region, Texas, 2006-11.

14. Approximate water-level changes in the Jasper aquifer, Houston-Galveston region, Texas, 2000-2011.

15. Location of borehole extensometer sites, Houston-Galveston region, Texas.

16. Graphs showing measured compaction of subsurface material, 1973-2010, at borehole extensometer sites shown on sheet 15.

\section{Figures}

1. Location of Houston-Galveston region study area, Texas

2. Hydrogeologic section of the Gulf Coast aquifer system in Harris County and adjacent counties, Texas

3. Hydrogeologic section of the Gulf Coast aquifer system in Fort Bend County, Texas

4. Hydrogeologic section of the Gulf Coast aquifer system in Montgomery and Harris Counties, Texas

5. Diagram depicting the mechanism of subsidence in an aquifer composed of sand and clay .8

6. Diagram depicting cross-sectional perspective of the borehole extensometer/piezometer (LJ-65-23-322) located at Pasadena, Texas

\section{Tables}

(Available online at http://pubs.usgs.gov/sim/3174/)

1. Data for the Chicot aquifer sheets 1,2,3,4, and 5: (1) approximate water-level altitudes, December 2010-February 2011, (2) water-level changes 2010-11, (3) approximate water-level changes 2006-11, (4) approximate water-level changes 1990-11, and (5) approximate water-level changes 1977-11 in the Houston-Galveston region, Texas.

2. Data for the Evangeline aquifer sheets 6, 7, 8, 9, and 10: (6) approximate waterlevel altitudes, December 2010-February 2011, (7) water-level changes 2010-11, (8) approximate water-level changes 2006-11, (9) approximate water-level changes 1990-11, and (10) approximate water-level changes 1977-11 in the Houston-Galveston region, Texas. 
3. Data for the Jasper aquifer sheets 11,12,13, and 14: (11) approximate water-level altitudes, December 2010-February 2011, (12) water-level changes 2010-11,

(13) approximate water-level changes 2006-11, and (14) approximate water-level changes 2000-11 in the Houston-Galveston region, Texas.

4. Data for sheet 16 , measured compaction of subsurface material at borehole extensometer sites, 1973-2010.

\section{Conversion Factors}

\section{Inch/Pound to SI}

\begin{tabular}{|c|c|c|}
\hline Multiply & By & To obtain \\
\hline \multicolumn{3}{|c|}{ Length } \\
\hline foot $(\mathrm{ft})$ & 0.3048 & meter $(\mathrm{m})$ \\
\hline mile (mi) & 1.609 & kilometer (km) \\
\hline \multicolumn{3}{|c|}{ Area } \\
\hline acre & 4,047 & square meter $\left(\mathrm{m}^{2}\right)$ \\
\hline square foot $\left(\mathrm{ft}^{2}\right)$ & 0.09290 & square meter $\left(\mathrm{m}^{2}\right)$ \\
\hline square mile $\left(\mathrm{mi}^{2}\right)$ & 2.590 & square kilometer $\left(\mathrm{km}^{2}\right)$ \\
\hline
\end{tabular}

\section{Vertical Datum}

Vertical coordinate information is referenced to the National Geodetic Vertical Datum of 1929 (NGVD 29) or the North American Vertical Datum of 1988 (NAVD 88).

Horizontal coordinate information is referenced to the North American Datum of 1927 (NAD 27). 



\title{
Water-Level Altitudes 2011 and Water-Level Changes in the Chicot, Evangeline, and Jasper Aquifers and Compaction 1973-2010 in the Chicot and Evangeline Aquifers, Houston-Galveston Region, Texas
}

\author{
By Michaela R. Johnson, Jason K. Ramage, and Mark C. Kasmarek
}

\section{Abstract}

Most of the subsidence in the Houston-Galveston region has occurred as a direct result of groundwater withdrawals for municipal supply, industrial use, and irrigation that depressured and dewatered the Chicot and Evangeline aquifers causing compaction of the clay layers of the aquifer sediments. This report, prepared by the U.S. Geological Survey, in cooperation with the Harris-Galveston Subsidence District, City of Houston, Fort Bend Subsidence District, and Lone Star Groundwater Conservation District, is one in an annual series of reports depicting water-level altitudes and water-level changes in the Chicot, Evangeline, and Jasper aquifers and compaction in the Chicot and Evangeline aquifers in the Houston-Galveston region. The report contains maps showing 2011 water-level altitudes for the Chicot, Evangeline, and Jasper aquifers; maps showing 1-year (2010-11) waterlevel-altitude changes for each aquifer; maps showing 5-year (2006-11) water-level-altitude changes for each aquifer; maps showing long-term (1990-2011 and 1977-2011) water-levelaltitude changes for the Chicot and Evangeline aquifers; a map showing long-term (2000-11) water-level-altitude change for the Jasper aquifer; a map showing locations of borehole extensometer sites; and graphs showing measured compaction of subsurface material at the extensometers from 1973, or later, through 2010. Tables listing the data used to construct each aquifer-data map and the compaction graphs are included.

Water levels in the Chicot, Evangeline, and Jasper aquifers were measured during December 2010-February 2011. In 2011, water-level-altitude contours for the Chicot aquifer ranged from 200 feet below North American Vertical Datum of 1988 (hereinafter, datum) in a small area in southwestern Harris County to 200 feet above datum in central to southwestern Montgomery County. Water-level-altitude changes in the Chicot aquifer ranged from a 40-foot decline to a 33-foot rise (2010-11), from a 10-foot decline to an 80 -foot rise (2006-11), from a 140-foot decline to a 100 -foot rise (1990-2011), and from a 120-foot decline to a 200-foot rise (1977-2011). In 2011, water-level-altitude contours for the Evangeline aquifer ranged from 300 feet below datum in north-central Harris County to 200 feet above datum at the boundary of Waller, Montgomery, and Grimes Counties. Water-level-altitude changes in the Evangeline aquifer ranged from a 43-foot decline to a 73-foot rise (2010-11), from a 40 -foot decline to a 160 -foot rise (2006-11), from a 200 -foot decline to a 240-foot rise (1990-2011), and from a 340-foot decline to a 260-foot rise (1977-2011). In 2011, water-levelaltitude contours for the Jasper aquifer ranged from 200 feet below datum in south-central Montgomery County to 250 feet above datum in east-central Grimes County. Water-levelaltitude changes in the Jasper aquifer ranged from a 45-foot decline to a 29-foot rise (2010-11), from a 90-foot decline to a 10 -foot rise (2006-11), and from a 190-foot decline to no change (2000-11). Compaction of subsurface materials (mostly in the clay layers) composing the Chicot and Evangeline aquifers was recorded continuously at 13 borehole extensometers at 11 sites. For the period of record beginning in 1973, or later, and ending in December 2010, cumulative clay compaction data measured by 12 extensometers ranged from 0.100 foot at the Texas City-Moses Lake site to 3.544 foot at the Addicks site. The rate of compaction varies from site to site because of differences in groundwater withdrawals near each site and differences among sites in the clay-to-sand ratio in the subsurface materials. Therefore, it is not possible to extrapolate or infer a rate of clay compaction for an area based on the rate of compaction measured at a nearby extensometer.

\section{Introduction}

The Houston-Galveston region-comprising Harris, Galveston, Fort Bend, Waller, and Montgomery Counties and adjacent parts of Brazoria, Grimes, Walker, San Jacinto, Liberty, and Chambers Counties (fig. 1)-represents one of the largest areas of subsidence in the United States. Allen (1969) described ground surface displacement (subsidence) as the last 


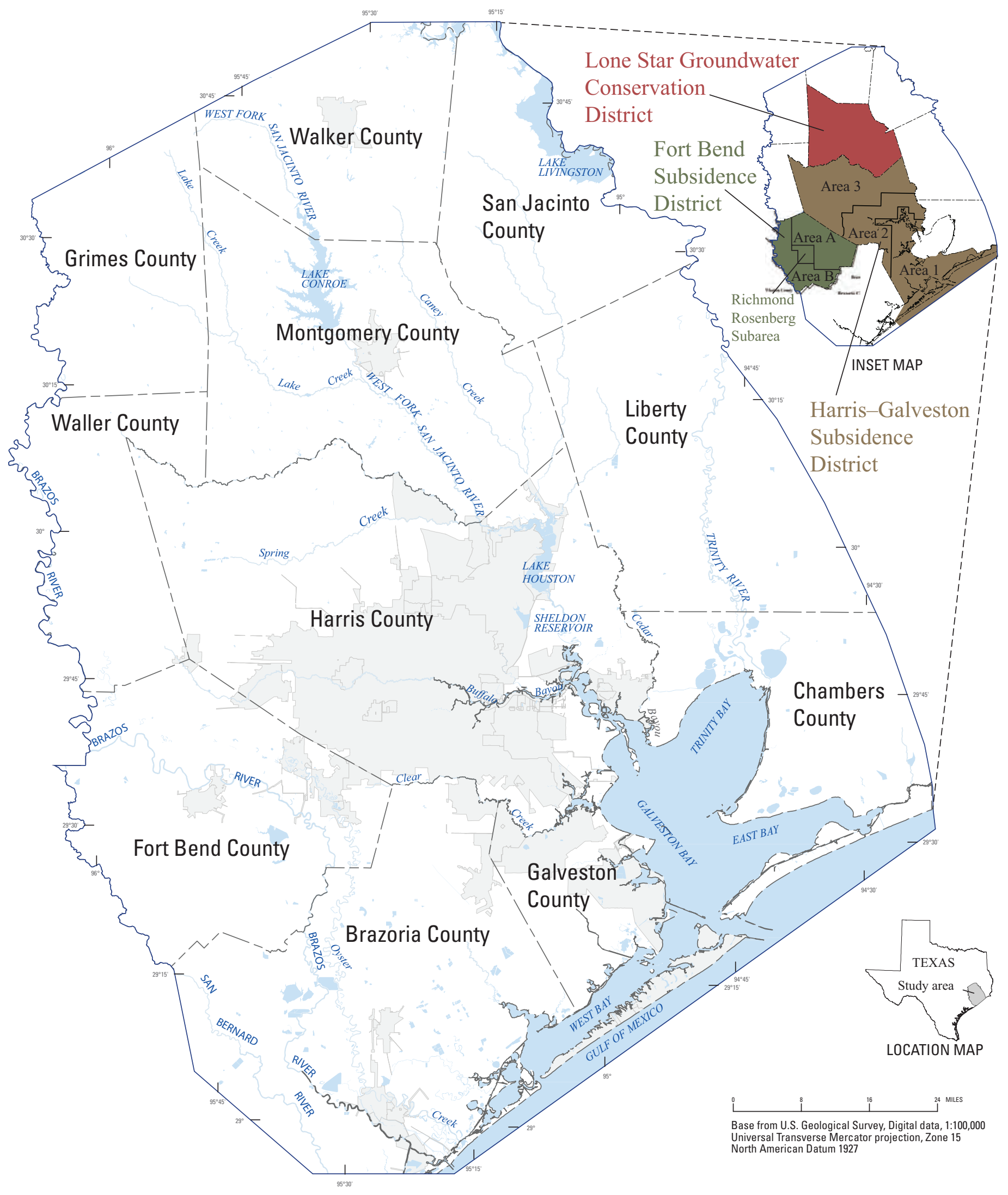

Figure 1. Location of Houston-Galveston region study area, Texas. 
step of a variety of subsurface displacement mechanisms that included (among others) compaction of sediments by loading, drainage, vibration, and hydrocompaction. By 1979, as much as 10 feet (ft) of subsidence had occurred in the HoustonGalveston region, and approximately 3,200 square miles $\left(\mathrm{mi}^{2}\right)$ of the 11,000-mi ${ }^{2}$ geographic area had subsided more than $1 \mathrm{ft}$ (Coplin and Galloway, 1999, p. 40). Comparing land-surface altitudes for 1915-17 to those for 2001, Kasmarek, Gabrysch, and Johnson (2010, sheet 2) determined that as much as $13 \mathrm{ft}$ of subsidence has occurred in southeastern Harris County.

Groundwater withdrawn from the Chicot, Evangeline, and Jasper aquifers has been the primary source of water for municipal supply and for commercial and industrial uses in the Houston-Galveston region since the early 1900s (Kasmarek and Robinson, 2004). Land-surface subsidence caused by fluid withdrawals was first documented in the Houston area in conjunction with the Goose Creek oil field in southeastern Harris County (Pratt and Johnson, 1926). Most of the subsidence in the Houston-Galveston region has occurred as a direct result of groundwater withdrawals for municipal supply, industrial use, and irrigation that depressured and dewatered the Chicot and Evangeline aquifers, thereby causing compaction of the clay layers of the aquifer sediments (Winslow and Doyle, 1954; Winslow and Wood, 1959; Gabrysch and Bonnet, 1975; Gabrysch, 1984; Holzer and Bluntzer 1984; Kasmarek, Johnson, and Ramage, 2010).

Subsidence is of particular concern in low-lying coastal areas such as the Houston-Galveston region. Land subsidence in the region has increased the frequency and severity of flooding (Coplin and Galloway, 1999). Low-pressure weather systems such as tropical storms and hurricanes cause high tides and high rates of precipitation, and subsidence exacerbates the effects of storm surge and impedes stormwater runoff by creating topographically low areas where water accumulates. Subsidence has shifted the coastline in parts of the Houston-Galveston region and changed the distribution of wetlands and aquatic vegetation (Coplin and Galloway, 1999). To address the issue of subsidence and its consequences, the Texas State Legislature in 1975 authorized the establishment of the Harris-Galveston Subsidence District (HGSD) to regulate and reduce groundwater withdrawals in Harris and Galveston Counties. In cooperation with the HGSD, the USGS has monitored water levels in the Chicot and Evangeline aquifers and clay compaction in Harris and Galveston Counties since 1976. The USGS has published annual reports of water-level altitudes and water-level changes for the Chicot and Evangeline aquifers in the Houston-Galveston region beginning with the 1977 water levels and annual reports of the same for the Fort Bend subregion (Fort Bend County and adjacent areas) beginning with the 1990 water levels. The USGS published its first annual reports of water-level altitudes and water-level changes for the Jasper aquifer in the greater Houston area (primarily Montgomery County) beginning in 2000. Compaction in the Houston-Galveston region has been presented in USGS reports of annual water-level altitudes and water-level changes since 1981 (compaction for 197381 ) and periodically was reported on separately by USGS authors since 1954 (for example, Winslow and Doyle, 1954; Gabrysch, 1984).

Subsequent to establishing the HGSD, the Texas State Legislature established an additional subsidence district (Fort Bend Subsidence District [FBSD]) and a groundwater conservation district (Lone Star Groundwater Conservation District [LSGCD]) in the Houston-Galveston region to provide for the regulation of groundwater in fast-growing inland areas (fig. 1). The FBSD was established in 1989 and has jurisdiction throughout Fort Bend County. The FBSD is divided into area A, which includes the Richmond-Rosenberg subarea, and area B. The LSGCD was established in 2001 and has jurisdiction throughout Montgomery County (fig. 1). The primary purpose of the HGSD and FBSD is to regulate groundwater withdrawal to prevent subsidence that contributes to flooding (Fort Bend Subsidence District, 2009; HarrisGalveston Subsidence District, 2010). The directive of the LSGCD is to conserve, protect, and enhance the groundwater resources of Montgomery County (Lone Star Groundwater Conservation District, 2011). Regulations to gradually change the source of water from groundwater to surface-water supplies are being phased in; the historical, current (2011), and future groundwater management plans of each district are available from their respective Web sites (Fort Bend Subsidence District, 2009; Harris-Galveston Subsidence District, 2010; Lone Star Groundwater Conservation District, 2011). In the seven other counties of the HoustonGalveston region (fig. 1, inset), groundwater withdrawals remain unregulated.

In 1976 the HGSD began implementing their first groundwater regulatory plan (Harris-Galveston Subsidence District, 2010). An extensive well monitoring network was established by 1977, and water-level data were collected and used to create the first published water-level-altitude maps of the Chicot and Evangeline aquifers in the Houston-Galveston area (Gabrysch, 1979). The FBSD adopted its groundwater management plan in 1990 (Fort Bend Subsidence District, 2009). After a comprehensive well monitoring network was established in Fort Bend, Harris, Brazoria, and Waller Counties in 1989 and 1990, the first water-level altitudes were published for the Chicot and Evangeline aquifers in 1991 (Barbie and others, 1991), and when updated well information became available, the current water-level altitudes were updated in 1997 (Kasmarek, 1997). Similarly, after the creation of the LSGCD in 2001, the USGS first published a water-level-altitude map for the Jasper aquifer in the Houston area (primarily Montgomery County) (Coplin, 2001). In 2004 and again in 2007, as additional wells with reliable water-level-measurement data were inventoried, revised water-level-altitude maps for the Jasper aquifer were prepared (Kasmarek and Lanning-Rush, 2004; Kasmarek, Houston, and Brown, 2006; Kasmarek and Houston, 2007). Compared to the 2001 and 2004 maps, the 2007 water-level map is the most comprehensive; the number of wells with reliable water-level data for the Jasper aquifer in the Houston area was sufficient in 2007 to produce a detailed map. 
Water-Level Altitudes 2011 and Water-Level Changes in the Chicot, Evangeline, and Jasper Aquifers

\section{Purpose and Scope}

This report is one in an annual series of reports that depicts water-level altitudes and water-level changes in the Chicot, Evangeline, and Jasper aquifers and compaction in the Chicot and Evangeline aquifers in the Houston-Galveston region. The report also describes the hydrogeology of the study area and provides an overview of the mechanism of clay compaction and land-surface subsidence.

This report contains maps (sheets 1-14) depicting water-level altitudes for 2011 for each of the three aquifers: maps depicting 1-year (2010-11) water-level changes for each aquifer; maps depicting 5-year (2006-11) water-level changes for each aquifer; maps depicting long-term (19902011 and 1977-2011) water-level changes for the Chicot and Evangeline aquifers, respectively; and a map depicting longterm (2000-11) water-level change for the Jasper aquifer. In addition to maps depicting water-level altitudes and changes in the Chicot, Evangeline, and Jasper aquifers, this report also contains graphs showing measured compaction of subsurface material in the Chicot and Evangeline aquifers for 12 borehole extensometers at 11 sites in Harris and Galveston Counties from 1973, or later, through 2010 and a location map for the borehole extensometers. Tables listing the data used to construct each of the maps and the compaction graphs also are included, as well as a brief description of the methods used for map construction.

\section{Hydrogeology of the Study Area}

The three primary aquifers in the Gulf Coast aquifer system are the Chicot, Evangeline, and Jasper (figs. 2-4), which are composed of laterally discontinuous deposits of gravel, sand, silt, and clay. The uppermost Chicot aquifer consists of Pleistocene- and Holocene-age sediments; the Evangeline aquifer consists of Miocene- and Plioceneage sediments; and the lowermost Jasper aquifer consists of Miocene-age sediments (Baker, 1979, 1986). Through geologic time, geologic and hydrologic processes created accretionary-sediment wedges (stacked sequences of sediments) more than 7,600 ft thick at the coast (fig. 2) (Chowdhury and Turco, 2006). The sediments composing the Gulf Coast aquifer system were deposited by fluvial-deltaic processes and subsequently were eroded and redeposited (reworked) by large episodic changes in sea level that occurred as a result of oscillations between glacial and interglacial climate conditions (Lambeck and others, 2002). The Gulf Coast aquifer system comprises hydrogeologic units that dip and thicken from northwest to southeast; the aquifers thus crop out in bands inland from and approximately parallel to the coast and become progressively more deeply buried and confined toward the coast (fig. 2). The Burkeville confining unit separates the Evangeline and Jasper aquifers and restricts groundwater flow between the two aquifers. There is no confining unit between the Chicot and Evangeline aquifers; therefore, the aquifers are hydraulically connected, allowing groundwater flow between the aquifers (fig. 2). Because of this hydraulic connection, changes in hydraulic head in the Evangeline aquifer affect water levels in the Chicot aquifer. Evidence of this can be seen by comparing the long-term change maps (1977-2011, sheets 5 and 10) and observing that areas where water levels have declined or risen in the Chicot aquifer are approximately coincident with areas where water levels have declined or risen, respectively, in the Evangeline aquifer. The Chicot aquifer can be differentiated from the geologically similar Evangeline aquifer on the basis of hydraulic conductivity (Carr and others, 1985, p. 10) and where each aquifer outcrops - the Chicot outcrops closer to the coast compared to the Evangeline. The Jasper aquifer outcrops inland from the Evangeline aquifer. The Jasper can be differentiated from the Evangeline aquifer on the basis of water levels, which are shallower (closer to land surface) in the Jasper aquifer compared to those in the Evangeline aquifer. In the downdip parts of the aquifer system, the Jasper aquifer can be differentiated from the Evangeline aquifer on the basis of stratigraphic position in relation to the Burkeville confining unit (figs. 2-4).

The hydrogeologic cross section $A-A^{\prime}$ (fig. 2) extends through the Houston-Galveston region from northwestern Grimes County, continues southeastward through Montgomery and Harris Counties, terminates at the coast in Galveston County, and shows the three aquifers thickening and dipping toward the coast. Comparison of cross section $A-A^{\prime}$ (fig. 2) to cross sections $B-B^{\prime}$ (fig. 3 ) in Fort Bend County and $C-C^{\prime}$ (fig. 4) in Montgomery and Harris Counties shows that the thicknesses of the three aquifers similarly increase toward the coast in these counties. In central Harris and southern Montgomery Counties, the sediments of the updip Chicot and Evangeline aquifers become progressively thinner (fig. 2), and in northern Montgomery County, the sediments of the Chicot aquifer are effectively nonexistent for groundwater withdrawal (fig. 4).

Water in the Chicot, Evangeline, and Jasper aquifers is fresh (less than 1,000 milligrams per liter [mg/L] dissolvedsolids concentration) in the Houston-Galveston region, but it becomes more saline in the downdip and more deeply buried parts of the aquifers near the coast (Baker, 1979). In the groundwater-flow system, water discharges to streams or recharges the aquifers in the unconfined outcrop areas moving downward and coastward (Kasmarek, Johnson, and Ramage, 2010). Water that does not discharge to streams flows to intermediate and deep zones of the system southeastward of the outcrop areas, and there the water is discharged by wells or by upward leakage in topographically low areas near the coast (Kasmarek and Robinson, 2004). Water in all three aquifers near the coast and at depth has dissolved-solids concentrations greater than $1,000 \mathrm{mg} / \mathrm{L}$. This more-saline water causes lessdense freshwater that has not been captured and discharged by wells to be redirected upward as diffuse upward leakage to shallow zones of the confined downdip areas of the aquifer system and is ultimately discharged to coastal brackish water bodies (Kasmarek and Robinson, 2004). 
缡
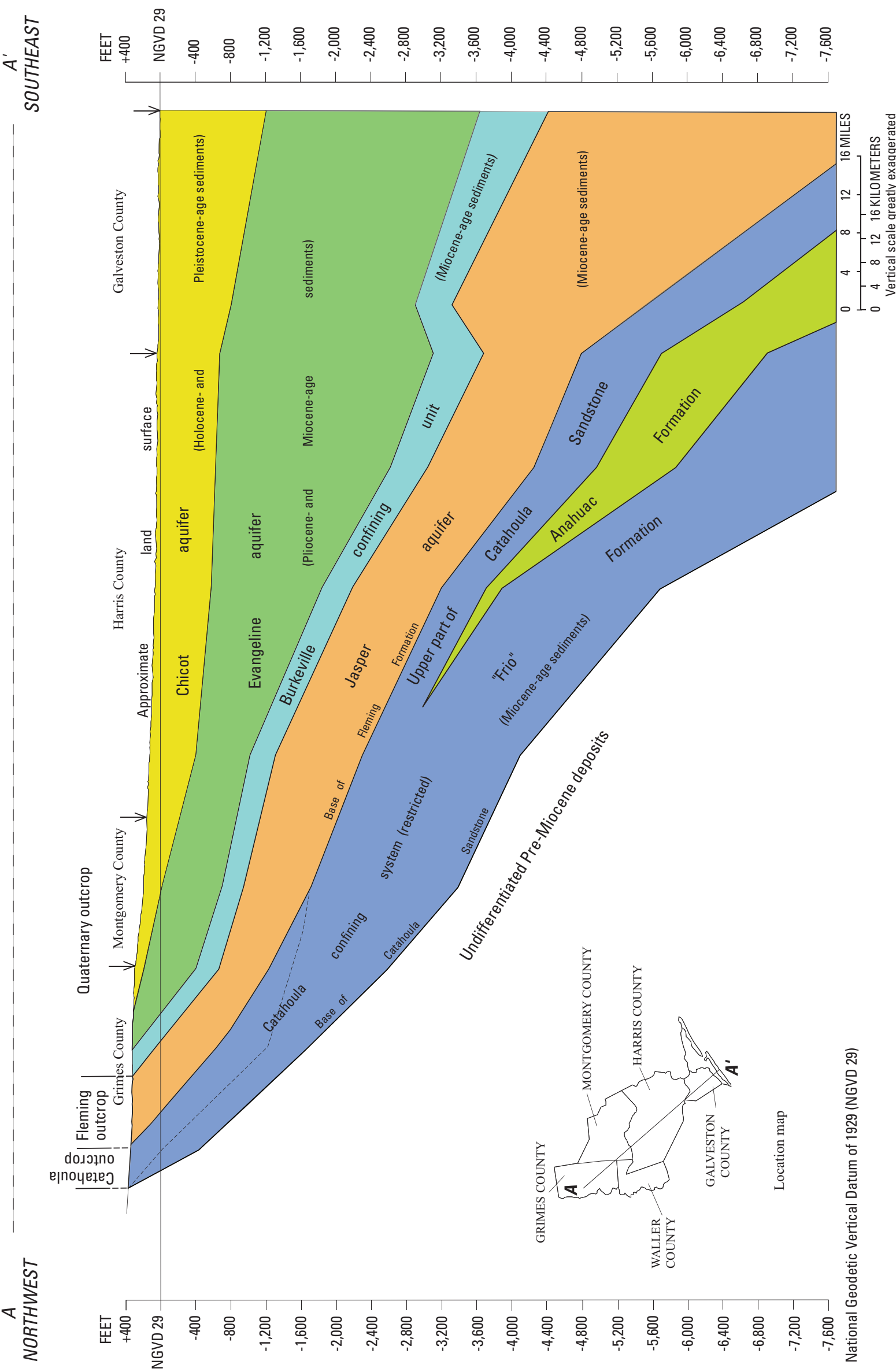

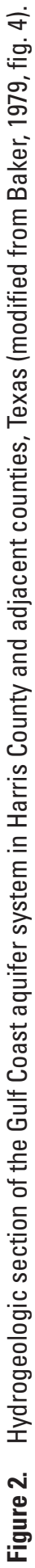




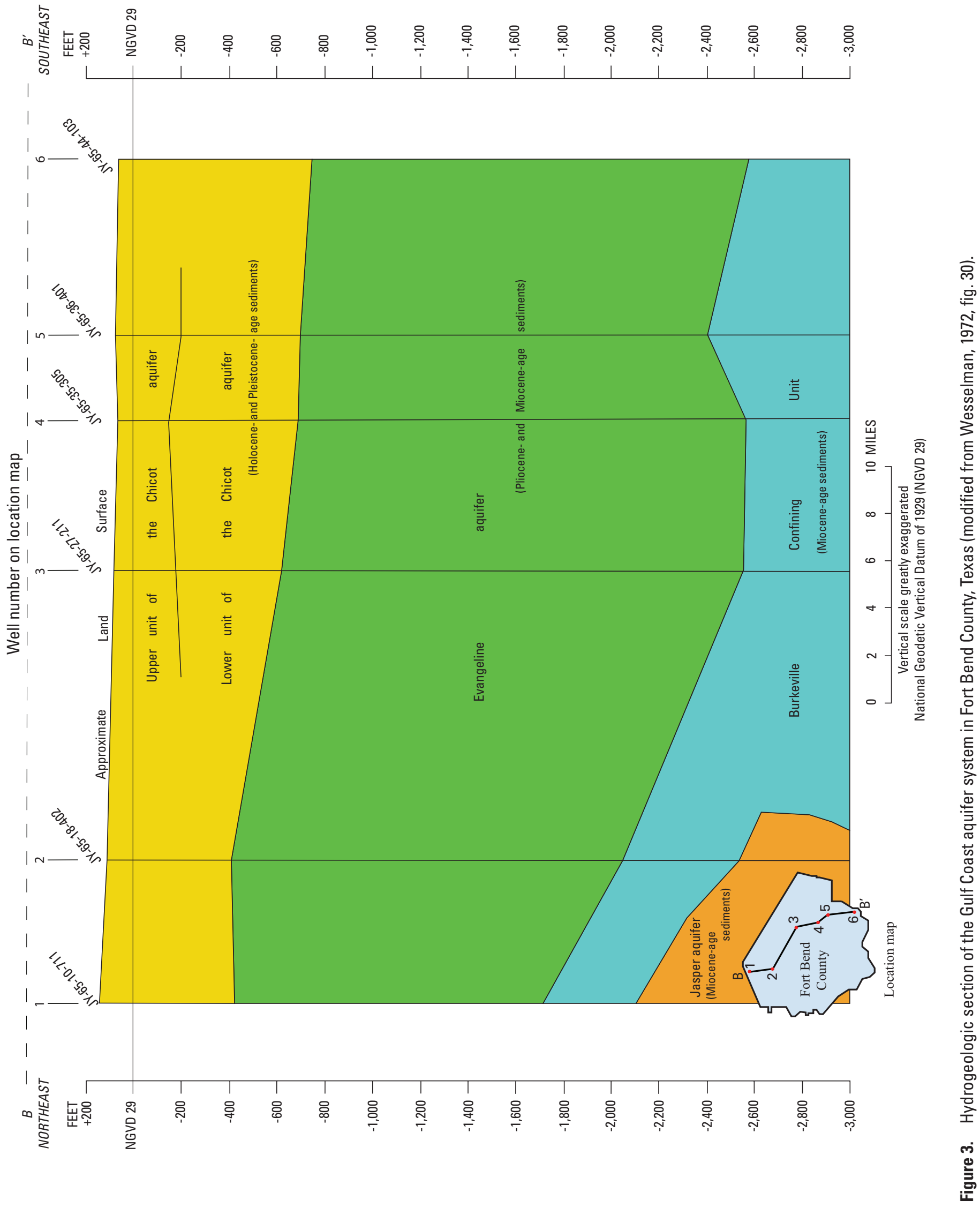




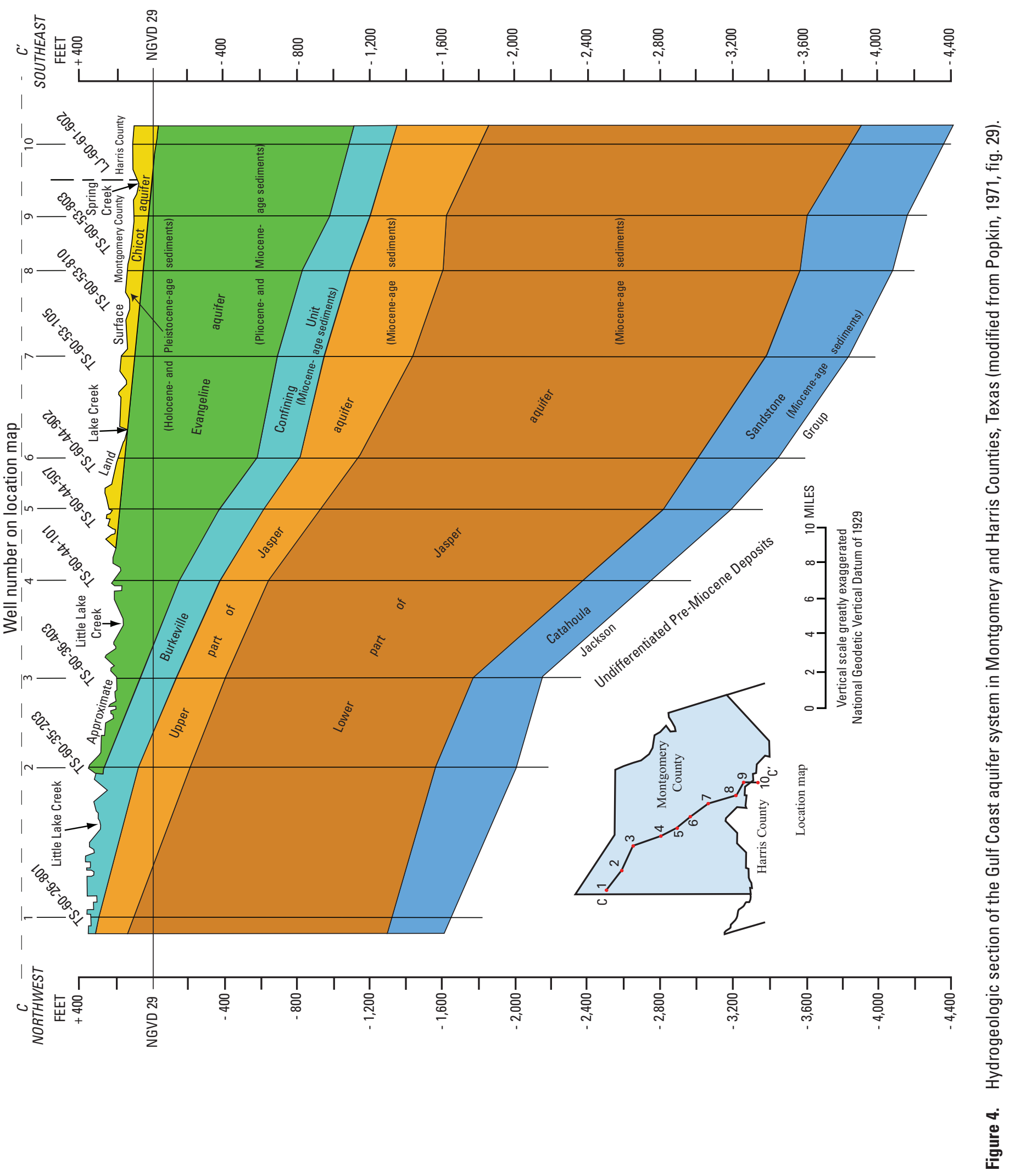




\section{Subsidence and Compaction Processes}

Subsidence can occur as a result of potentiometricsurface declines in unconsolidated confined aquifers (Galloway and others, 1999). Potentiometric-surface declines cause a decrease in hydraulic pressure (depressuring) that creates a load on the skeletal matrix of the sediments in the aquifer and adjacent confining units (fig. 5). Because sand layers are more transmissive and less compressible than clay layers, sand layers depressure more rapidly compared to clay layers. In addition, when groundwater withdrawals are decreased, pressure equilibrium is reestablished more rapidly in the sand layers compared to the clay layers, and the amount of compaction of the sand layers is usually minor compared to the amount of compaction of the clay layers (Trahan, 1982; Galloway and others, 1999). The clay layers are often interbedded within the sand layers, and when depressurizing occurs this results in a slower dewatering of the clay layers compared to the sand layers. The compressibility of the clay layers is dependent on the thickness and hydraulic characteristics of the clay layers and the vertical stress of the sediment overburden. Slow drainage of the clay layers continues to occur until the excess residual pore pressure in the clay layers equilibrates with the pore pressure of the adjacent sand layers. As dewatering progresses, compaction of the clay layers continues until pressure equilibrium is attained. A similar loading process can occur in sand layers; however, a major difference is that the orientation of the individual clay grains realigns as dewatering progresses, becoming perpendicular to the applied vertical overburden load (Galloway and others, 1999). Therefore, the dewatering caused by the depressurization of the clay layers results in clay-grain realignment and thus reduces the porosity and groundwater-storage capacity of the clay layers as compaction occurs (fig. 5). Essentially, the water stored in the clay layers prior to depressuring provides the strength to the clay skeleton, and when the clay layer is dewatered, the clay skeleton collapses without the water to support it, which leads to compaction. Because most compaction of the clay layers is inelastic, about 90 percent of the compaction is permanent (Gabrysch and Bonnet, 1975). In areas where groundwater withdrawals have decreased, the water level in the aquifers rises and repressures the compacted clay layers, but only a small amount of rebound of the land-surface altitude occurs (Gabrysch and Bonnet, 1975). Although the compaction of one thin clay layer generally will not cause a noticeable decrease in the land-surface altitude, when numerous stacked clay- and sand-layer sequences (characteristic of the Gulf Coast aquifer system) depressure and compact, subsidence often occurs (Gabrysch and Bonnet, 1975).

\author{
When long-term withdrawals \\ lower groundwater levels \\ and raise pressure on the \\ clay and silt beyond a threshold \\ amount, the clay and silt \\ compact, and the land surface \\ subsides permanently.
}

\section{Original land surface}

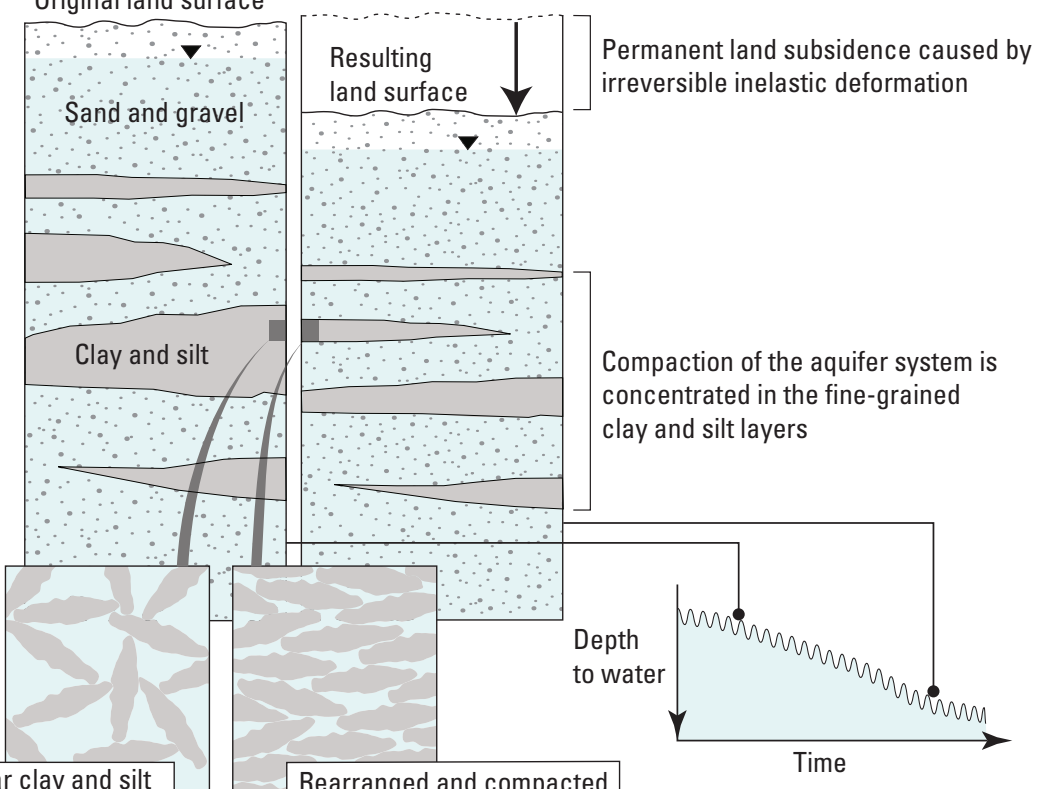

Rearranged and compacted granular clay and silt skeleton with reduced groundwater storage capacity
Long-term water-level decline modulated by the seasonal cycles of groundwater withdrawals

Figure 5. Diagram depicting the mechanism of subsidence in an aquifer composed of sand and clay (modified from Galloway and others, 1999, p. 9). 


\section{Data Collection and Analysis Methods}

Water-level data were obtained from wells by measuring the depth to water below land surface at each well. Measurements were obtained by using calibrated steel tape, air line, and electric water-level tape and also were obtained from reports of well operators. Antecedent pumping conditions and pumping status of nearby wells were not always known, although most wells were pumped at least once daily and some more frequently. A minimum of two water-level measurements were made at each well while the well was not being pumped. To ensure that the water-level measurement recorded for each well was accurate, additional water-level measurements were made as required. Water-level-measurement data used to create sheets 1-14 of this report were collected during December 2010-February 2011 (tables 1-3); during winter months, water levels in the Houston-Galveston region are usually higher compared to the rest of the year because rates of groundwater withdrawals are at a minimum. Subsequently, these data were incorporated into a geographic information system (GIS) as point-data layers and used for the construction of sheets $1-14$.

\section{Determination of Water-Level Altitudes}

The water-level-altitudes used to construct the waterlevel-altitude maps for the Chicot, Evangeline, and Jasper aquifers (sheets 1, 6, and 11, respectively) were calculated by subtracting the water-level measurement from the land-surface-altitude value for each well (point). Landsurface altitudes were referenced to the North American Vertical Datum of 1988 (NAVD 88) (National Oceanic and Atmospheric Administration, 2008). Therefore, each point used for contour configuration on the three water-level-altitude maps is referenced to NAVD 88 (tables 1-3). Water-level altitudes are depicted with contour intervals of 25 and $50 \mathrm{ft}$.

\section{Depicting Changes in Water-Level Altitudes}

Maps depicting changes in water-level altitudes in the Chicot, Evangeline, and Jasper aquifers were prepared for 2010-11, 2006-11, 1990-2011 (Chicot and Evangeline), 1977-2011 (Chicot and Evangeline), and 2000-11 (Jasper). To create the various water-level-change maps, datasets of water-level-change values (difference between the current year [2011] and historical water-level-altitude values) were used. The historical year water-level altitudes were obtained from the first maps published as part of the annual series for HGSD, FBSD, and LSGCD depicting water-level altitudes in 1977, 1990, and 2000, respectively (Gabrysch, 1979; Kasmarek, 1997; Kasmarek and Houston, 2007).

For the 1-year (2010-11) water-level-change maps (sheets 2, 7, and 12), water-level-changes were computed as the difference between water-level altitude at each point (well) for which a water-level measurement was made in 2010 and in 2011. Water-level changes are shown as a blue triangle (water-level rise), a red inverted triangle (water-level decline), or a circle (no water-level change).

For the 5-year (2006-11) change maps (sheets 3, 8, and 13), water-level changes were computed the same as for the 1-year maps - the difference between water-level altitude at each well for which a water-level measurement was made in 2011 and 2006. Changes on the 5-year maps are indicated by contours of equal water-level change. Each 5-year map was prepared by contouring the set of mapped point differences.

For the historical (1990-2011, 1977-2011, 2000-11) change maps (sheets $4,5,9,10$, and 14), water-level changes were computed as the difference between water-level altitude at each well for which a water-level measurement was made in 2011 and in the historical year (1990, 1977, and 2000). For wells measured in 2011 that had no corresponding measurement in the historical year, a GIS raster (gridded surface) (Worboys, 1995) was created from published historical water-level-altitude contours (1990, 1977, and 2000). The maps were created by contouring the set of mapped point values computed as either the difference in water-level altitude at each point (well) for which a water-level measurement was made in 2011 and in the historical year, or the difference in water-level altitude at that point in 2011 and the water-level altitude on a gridded surface of the historical year water-level-altitude map (Gabrysch, 1979; Kasmarek, 1997; Kasmarek and Houston, 2007). Gridded-surface values for the historical year (rather than actual measured values) were used to compute differences (mapped point values) because many of the wells measured in the historical year have been destroyed or were not measured in 2011. For the subset of wells measured in both 2011 and the historical year, the mapped point values used were the differences in water-levelaltitude values between 2011 and the historical year rather than the differences between 2011 water-level-altitude values and historical year gridded-surface values.

In the Houston-Galveston region, water-level-altitude contours represent 2011 regional-scale depictions of the water levels in the Chicot, Evangeline, and Jasper aquifers. The areal extent and location of these contours represent the combined effect of groundwater withdrawals at all groundwater wells in the study area. Similarly, water-level-change contours represent regional-scale depictions of water-level change during selected periods for each aquifer. Delineated areas showing contours of water-level rise or decline represent water-level changes in the aquifers caused by spatial and temporal changes in groundwater withdrawals.

\section{Borehole Extensometers}

To install a borehole extensometer, a borehole is first drilled to a predetermined depth, generally below the depth of expected water-level decline. A steel outer casing with slip joints is then installed in the borehole from $1 \mathrm{ft}$ above land surface to $5 \mathrm{ft}$ above a cement plug placed at the bottom of the borehole (total depth of the borehole is from land surface to 
cement plug), and a smaller diameter pipe (inner pipe; often referred to as the "extensometer pipe") is inserted inside the outer casing, with the inner pipe terminating within the cement plug and extending above land surface (fig. 6). The slip joints in the outer casing prevent crumpling and collapse of the outer casing as clay compaction associated with a decrease in landsurface altitude occurs, while the inner pipe remains fixed and rigid. At land surface, a concrete slab is poured and connected to an array of vertical concrete piers extending down to the water table. This construction design helps to eliminate the continuous shrinking and swelling of the clayey surficial sediments associated with soil-moisture changes. The concrete piers connect the slab to the underlying unconsolidated sediments penetrated by the borehole. A gage house is constructed on the slab, and a steel-table-mounted recorder is installed in the gage house. A calibrated steel tape connects the recorder to the top of the inner pipe; because the steel table is anchored to the slab, changes in land-surface altitude can be accurately measured and recorded. These recorded values represent the cumulative clay compaction at the site. The scientific theory and operation of a borehole extensometer is further explained by Gabrysch (1984).

Extensometer data are used to quantify the rate of compaction in aquifer formations, thereby providing water-resource managers a tool for evaluating the effects on subsidence rates caused by changes in the amount of groundwater withdrawn from the Chicot and Evangeline aquifers. For this report, borehole extensometer data of the compaction of subsurface material in the Chicot and Evangeline aquifers were evaluated at 13 borehole extensometers at 11 sites in Harris and Galveston Counties. To quantify the rate of compaction in aquifer formations, a network of extensometers was installed beginning in 1973 at selected sites throughout Harris and Galveston Counties. Five extensometers were installed in Harris or Galveston County in July 1973: KH-64-33-920 (Texas City-Moses Lake) in Galveston County and LJ-65-22-622 (East End), LJ-6516-930 (Baytown C-1), LJ-65-16-931 (Baytown C-2), and LJ-65-32-625 (Seabrook) in Harris County. A previously existing borehole extensometer installed in 1962 in Harris County (LJ-65-32-401 [Johnson Space Center]) was included in the network, and routine measurements of compaction obtained at the Johnson Space Center since July 1973 are included in this report. Additional extensometers were added to the network during 1974-76 in Harris County: LJ-65-12726 (Addicks) in 1974, LJ-65-23-322 (Pasadena) in 1975, and LJ-65-32-428 and LJ-65-32-424 (Clear Lake) in 1976. The last three extensometers in the current (2011) network were installed in Harris County in 1980: LJ-65-07-909 (Lake Houston), LJ-65-14-746 (Northeast), and LJ-65-21-226

(Southwest). Since activation or installation between 1973 and 1980, compaction measurements have been obtained at these 13 extensometers at least monthly of site-specific rates of compaction accurate within $0.001 \mathrm{ft}$.

Each borehole extensometer has a $10-\mathrm{ft}$ open interval at depth and above the cement plug that allows water to flow into the center pipe and thus functions as a piezometer (small-diameter well used to measure water-level altitudes). A water-level measurement is made during each extensometer site visit. If the depth of the screened interval is in the Chicot or Evangeline aquifer, these water-level measurements are considered during construction of the annual water-levelaltitude map for those aquifers.

\section{Quality Assurance}

Protocols for the collection and review of water-levelaltitude data were followed that are described in the USGS Texas Water Science Center "Quality Assurance Plan for Groundwater Activities" (appendix 7.3, "Groundwater Data Management Plan" [Greg Stanton, U.S. Geological Survey, written commun., 2010]). All data were stored in the USGS National Water Information System (NWIS) (U.S. Geological Survey, 2011).

The annual (2011) regional depictions of water-level altitudes presented in this report were derived from waterlevel-measurement data collected during December 2010February 2011 throughout an 11-county area that includes the greater Houston-Galveston area. The water-level altitudes of the Chicot, Evangeline, and Jasper aquifers change in response to changes in hydrologic conditions and groundwater pumping rates; water-level-altitude changes might have occurred since the most recent water-level measurements were made. Antecedent withdrawal rates and pumping status of nearby wells were not always known and could have affected the representativeness of the water-level data that were collected.

\section{Water-Level Altitudes and Changes}

Locations of wells used to construct the water-levelaltitude and water-level-change maps for the Chicot, Evangeline, and Jasper aquifers are shown in appendix 1. The well index numbers on the three maps (appendixes 1.1, 1.2, and 1.3) coincide with tabular data (tables 1-3) for each waterlevel altitude or water-level-change map, and the well symbols (small circles) show the geographic location of the well.

The Chicot and Evangeline aquifer maps show approximate water-level altitudes in 2011 and water-level changes for 2010-11, 2006-11, 1990-2011, and 1977-2011 (sheets 1-5 and 6-10, respectively). Depictions of long-term water-level change (1977-2011) show areas of decline in northern, northwestern, and southwestern Harris County and a broad area of water-level rise in southeastern Harris and northern Galveston Counties.

The Jasper aquifer maps show approximate waterlevel altitudes in 2011 and water-level changes for 2010-11, 2006-11, and 2000-11 (sheets 11-14). Depictions of longterm water-level change (2000-11) show that water-level declines have occurred in most of Montgomery County and north-central Harris County. 


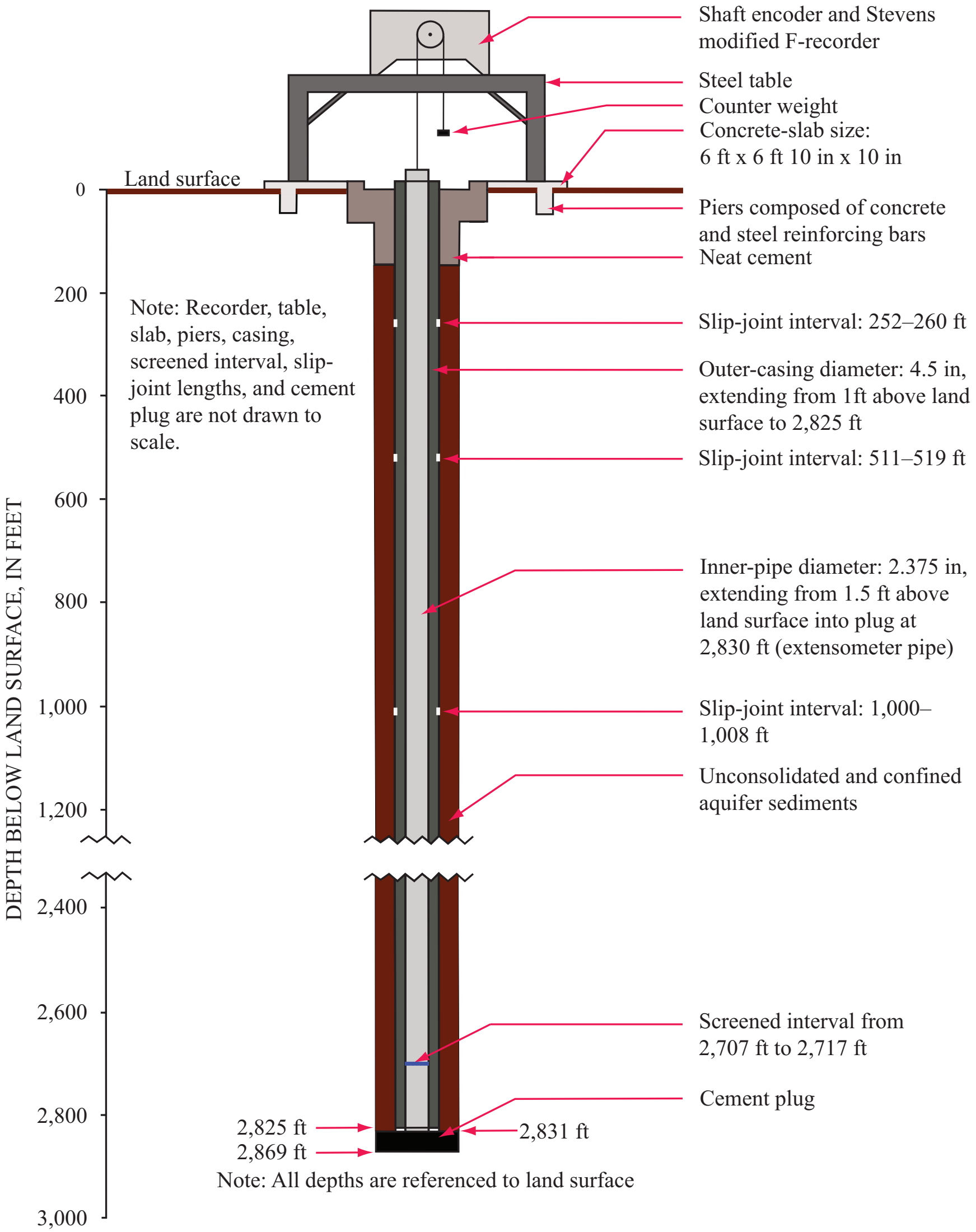

Figure 6. Diagram depicting cross-sectional perspective of the borehole extensometer/piezometer (LJ-65-23-322) located at Pasadena, Texas [ft, foot; in, inch]. 
Except for the 2010-11 change maps, the water-levelaltitude contours were prepared by using contour intervals specific to the range of water-level-altitude changes for a given map. Adjusting the contour intervals in this way helped to present a clear depiction of regional water-levelaltitude changes.

\section{Chicot Aquifer}

Water-level measurements from 178 wells (table 1) were used to construct the 2011 water-level-altitude map of the Chicot aquifer. In 2011, water-level-altitude contours ranged from $200 \mathrm{ft}$ below NAVD 88 (hereinafter, datum) in a small area in southwestern Harris County to $200 \mathrm{ft}$ above datum in central to southwestern Montgomery County (sheet 1). The water-level-change maps for 2010-11, 2006-11, 1990-2011, and 1977-2011 are shown on sheets 2, 3, 4, and 5, respectively. The numbers of water-level-measurement pairs used to construct the change maps were 169 for 2010-11, 164 for 2006-11, 149 for 1990-2011, and 139 for 1977-2011 (table 1).

Changes in water-level altitudes in the Chicot aquifer during 2010-11, depicted by numbered symbols on the sheets, ranged from a 40-ft decline in northeastern Fort Bend County to a 33-ft rise in southwestern Harris County (sheet 2). During 2006-11, contoured changes in water-level altitudes ranged from two 10-ft declines in southwestern and eastern Harris County to an 80 -ft rise in southwestern Harris County (sheet $3)$. For 1990-2011, changes in water-level altitude ranged from a 140-ft decline in northwest-central Harris County to a 100 -ft rise in south-central Harris County (sheet 4). For 19772011, contoured changes in water-level altitude ranged from a $120-\mathrm{ft}$ decline in north-central Harris County to a $200-\mathrm{ft}$ rise in southeastern Harris County (sheet 5). The long-term waterlevel change (1977-2011) depictions show areas of decline in northern, northwestern, and southwestern Harris County and a broad area of water-level rise in southeastern Harris and northern Galveston Counties.

\section{Evangeline Aquifer}

Water-level measurements from 349 wells (table 2) were used to construct the 2011 water-level-altitude map of the Evangeline aquifer. In 2011, water-level-altitude contours ranged from $300 \mathrm{ft}$ below datum in south-central Montgomery County to $200 \mathrm{ft}$ above datum at the intersecting borders of Waller, Montgomery, and Grimes Counties (sheet 6). Water-level-change maps for 2010-11, 2006-11, 19902011, and 1977-2011 are shown on sheets 7, 8, 9, and 10, respectively. The numbers of water-level-measurement pairs used to construct the change maps were 322 for 2010-11, 304 for 2006-11, 283 for 1990-2011, and 272 for 1977-2011 (table 2).

For the period 2010-11 in the Evangeline aquifer, waterlevel change (depicted by numbered symbols) ranged from a $43-\mathrm{ft}$ water-level decline in eastern Waller County to a $73-\mathrm{ft}$ rise in southwestern Harris County (sheet 7). For 2006-11, contoured changes in water-level altitude ranged from $40-\mathrm{ft}$ declines in central and south-central Montgomery County and eastern Waller County to a $160-\mathrm{ft}$ rise in southwest-central Harris County (sheet 8). For 1990-2011, contoured changes in water-level altitude ranged from a $200-\mathrm{ft}$ decline in southcentral Montgomery County to a 240 -ft rise in southeastern Harris County (sheet 9). For 1977-2011, contoured change ranged from a $340-\mathrm{ft}$ decline near the border of Harris and Montgomery Counties to a $260-\mathrm{ft}$ rise in southeastern Harris County (sheet 10). The long-term water-level change (1977-2011) depictions show areas of decline in northern, northwestern, and southwestern Harris County and a broad area of water-level rise in southeastern Harris and northern Galveston Counties.

\section{Jasper Aquifer}

Water-level measurements from 106 wells (table 3) were used to construct the 2011 water-level-altitude map of the Jasper aquifer. For 2011, water-level-altitude contours ranged from $200 \mathrm{ft}$ below datum in south-central Montgomery County to $250 \mathrm{ft}$ above datum in east-central Grimes County (sheet 11).

Water-level-change maps for 2010-11, 2006-11, and 2000-11 are shown on sheets 12,13 , and 14, respectively. The numbers of water-level-measurement pairs used to construct the change maps were 93 for 2010-11, 91 for 2006-11, and 92 for 2000-11 (table 3).

For the period 2010-11 in the Jasper aquifer, waterlevel change (depicted by numbered symbols) ranged from a $45-\mathrm{ft}$ decline in north-central Montgomery County to a $29-\mathrm{ft}$ rise in north-central Harris County (sheet 12). For 2006-11, contoured changes in water-level altitude ranged from a $90-\mathrm{ft}$ decline in south-central Montgomery County to a 10-foot rise in north-central Harris County (sheet 13). For 2000-11, water-level declines occurred in most of Montgomery County and north-central Harris County; contoured changes in water-level altitude ranged from a 190 -ft decline in southcentral Montgomery County to no change in far northwestern Montgomery County (sheet 14).

\section{Compaction in the Chicot and Evangeline Aquifers}

Compaction of subsurface materials (mostly of the clay layers because little compaction occurs in sand layers; refer to "Subsidence and Compaction Processes" section) composing the Chicot and Evangeline aquifers was recorded continuously at the 13 borehole extensometers at 11 sites (sheet 15) by using analog chart recorders. The rate of compaction varies from site to site (sheet 16). Graphs of compaction are shown for 1973, or later, through 2010 (depending on when each extensometer was installed) for 12 of the 13 extensometers 
(sheet 16); compaction data for the graphs are listed in tables $4 A-L$. Compaction measured by the proximal and shallower of the two borehole extensometers at the Clear Lake site (LJ-65-32-424) is not shown because the recorded data are similar to that measured by the deeper borehole extensometer (LJ-65-32-428) at the site. The selected depth of the extensometer determines the total thickness of sediment over which clay compaction is measured by the extensometer. Five extensometers measure clay compaction in the sediments of the Chicot aquifer (East End [LJ-65-22-622], Johnson Space Center [LJ-65-32-401], Texas City-Moses Lake

[KH-64-33-920], Baytown C-1 [LJ-65-16-930], Seabrook [LJ-65-32-625]), and seven extensometers measure compaction in the sediments of the Chicot and Evangeline aquifers (Lake Houston [LJ-65-07-909], Northeast [LJ-65-14-746], Southwest [LJ-65-21-226], Addicks [LJ-65-12-726], Baytown C-2 [LJ-65-16-931], Clear Lake [LJ-65-32-428], Pasadena [LJ-65-23-322]) (sheet 16). Since the early $1900 \mathrm{~s}$, as much as $12-13 \mathrm{ft}$ of historical subsidence has occurred in the Pasadena and Baytown areas in Harris County (Kasmarek, Gabrysch, and Johnson, 2010). The graphs of cumulative-compaction data from installation in 1975 through 2010 for the Pasadena extensometer and from installation in 1973 through 2010 for the two Baytown extensometers indicate compaction values of $0.346,0.823$, and $1.015 \mathrm{ft}$, respectively (sheet 16 ; tables $4 L, 4 H$, and $4 I$, respectively). Most of the land-surface subsidence

(77 to 97 percent) in the Houston-Galveston region occurred prior to 1973, when the installation of extensometers began

(Kasmarek, Gabrysch, and Johnson, 2010).

Prior to the creation of HGSD, the withdrawal of groundwater from the Chicot and Evangeline aquifers was unregulated, and the associated compaction of clay layers was ongoing as water levels in the aquifers were declining. By 1977, the withdrawals had resulted in water-level-altitude declines of 300 and $350 \mathrm{ft}$ below datum in the Chicot and Evangeline aquifers, respectively, in southeastern Harris County (Gabrysch, 1979). The rate of compaction varies from site to site because of differences in groundwater withdrawals near each site and differences among sites in the clay-to-sand ratio of the subsurface materials. When reductions in groundwater withdrawals were first mandated following the creation of the HGSD in 1975, the rate of groundwater withdrawal began to decrease along with the rate of clay compaction (sheet 16). Coincident with the curtailment of groundwater withdrawals, the aquifer water levels began to rise. Water levels in the Chicot and Evangeline aquifers have risen as much as 200 and $260 \mathrm{ft}$, respectively, as shown on the 1977-2011 long-term-change maps (sheets 5 and 10, respectively).

For the period of record ending December 2010, cumulative clay compaction in the Chicot and Evangeline aquifers (sheet 16) ranged from $0.100 \mathrm{ft}$ (table $4 G$ ) at the Texas City-Moses Lake extensometer to $3.544 \mathrm{ft}$ (table $4 E$ ) at the Addicks extensometer. The graphs of cumulativecompaction data show that the compaction rates were substantially greater when the extensometers were initially installed compared to compaction rates in subsequent years. These asymptotic compaction-rate decreases were directly related to the rise in water levels in the aquifers as groundwater withdrawals were decreased in response to regulatory mandates of the HGSD. As the water level of the aquifers began to rise or rebound, the hydrostatic pressure increased, and excess, residual pore pressure equilibrated, hence the rates of compaction progressively decreased. Coinciding with compaction-rate decreases, the long-term water-level changes for 1990-2011 and 1977-2011 in the Chicot and Evangeline aquifers (sheets 4 and 5 and sheets 9 and 10, respectively) show that, except for the Addicks extensometer, the locations of these extensometers coincide with the relatively large area of water-level rise. Compaction data from the Addicks extensometer (table $4 E$ ) show that the rate of compaction continued steadily through mid-2003. The reason the rate remained steady during this period is that the extensometer is located in Regulatory Area 3 of HGSD and, as such, was not scheduled for a 30-percent groundwater reduction until 2010 (Harris-Galveston Subsidence District, 2010). Therefore, from mid-1974 through mid-2003, groundwater withdrawal continued in the area adjacent to the Addicks extensometer site with an associated claycompaction rate of about $0.1 \mathrm{ft}$ per year. Additionally, the rate of compaction during about August 2003-December 2003 decreased to about $0.004 \mathrm{ft}$ because an adjacent public-supply well field was inoperative during this period. From December 2003 until March 2006, recorded data indicated an increase (rebound) in land-surface altitude of about $0.030 \mathrm{ft}$. The graph of compaction for the Seabrook extensometer shows a seasonal sinusoidal trend that indicates that the altitude of the land surface decreases in the hot and dry summer months as the surficial clayey sediments desiccate. As the heat of the summer dissipates and the cooler and wetter months arrive, the sediments rehydrate, thereby causing the altitude of the land surface to increase and heave upward.

Compaction data for the Texas City-Moses Lake site indicate that not only has the rate of compaction been halted but also, since about 1981, a slight land-surface rise of approximately $0.09 \mathrm{ft}$ has occurred. The graphs of compaction data for the Pasadena, Clear Lake, Seabrook, Baytown $\mathrm{C}-1$ and $\mathrm{C}-2$, and Johnson Space Center extensometers indicate a slight increase in land-surface altitude from late1978 to early-1980 because of a ruptured natural gas well that pressurized the aquifer system and caused water levels to rise in the area adjacent to the well (Gabrysch, 1984). Over a period of about 2 years, the pressure in the aquifer slowly dissipated, and the rates of compaction returned to rates similar to the pre-pressuring-event rates. The graphs of compaction data for the two Baytown extensometers show a noticeable amount of seasonal change from late 1973 to late 1982, most likely caused by the expansive characteristic of the montmorillonitic clay composing the aquifer sediments. When soil moisture is comparatively low in summer, the surficial clays of the sediments compress, or shrink, thereby causing 
a decrease in land-surface altitude. Conversely, when soil moisture is comparatively high in winter, the clays expand, or swell, thereby causing an increase in land-surface altitude. To address the problem of shrinking and swelling clays, a modification was made in 1982 to the original design of the borehole extensometers by installing a system of vertical piers connected to the concrete bases of the extensometers and extending downward to the depth of the water table.

\section{Data Limitations}

Most land-surface altitudes for wells in this report are estimates from USGS 7.5-minute topographic quadrangle maps. Land-surface altitudes for 2009 and later for the wells in Harris County are derived from the 2001 Tropical Storm Allison Recovery Project (TSARP) light detection and ranging (LiDAR) digital elevation model (DEM) (Harris County Flood Control District, Tropical Storm Allison Recovery Project, 2002). These altitudes are referenced to NAVD 88 by using Corpscon version 6 (U.S. Army Corps of Engineers, 2006). LiDAR data were contoured at a $1-\mathrm{ft}$ interval, providing 0.5 -ft accuracy. The 7.5-minute topographic maps for the Gulf Coast area were normally contoured at a 5-ft interval, thereby providing a 2.5 -ft accuracy; thus, the LiDAR data provided about five times better accuracy when compared to topographic maps (Kasmarek, Gabrysch, and Johnson, 2010). In addition, the 7.5-minute topographic maps have not been updated with changes in land-surface altitude that might have occurred since publication of the map. The effects of land-surface-altitude changes on water-level-change maps are unavoidable if the change maps are to accurately reflect differences between current-year and previous-year waterlevel-altitude maps (each of which reflects the best available land-surface altitudes of wells).

The depictions of water-level altitudes and changes at any specific location are considered to represent a regionalscale approximation and, as such, are not intended for use in engineering or other design applications. The waterlevel measurements collected for this report were rounded to the nearest foot; the values shown on the maps represent a mathematical approximation that could vary as much as $\pm 0.5 \mathrm{ft}$, in addition to accuracies associated with the source data. Use of these data for critical or local-scale applications is not advised without full awareness of the data limitations. Users need to exercise discretion when drawing conclusions or making policy decisions on the basis of these contoured depictions.

Compaction data recorded at each extensometer site (sheet 16) are the cumulative compaction for all subsurface materials above the depth of the cement plug (fig. 6); any compaction or vertical movement that occurs below these depths is not measured by the extensometer. The compaction of subsurface material for a given extensometer could be occurring solely in the sediments of the Chicot aquifer (for example, the Baytown $\mathrm{C}-1$ extensometer) or in both the sediments of the Chicot and Evangeline aquifers (for example, the Addicks extensometer). In addition to differences in groundwater withdrawals near each extensometer, the clay-to-sand ratio is different at each site; hence, the rate of compaction varies from site to site (sheet 16). Therefore, it is not possible to extrapolate or infer a rate of clay compaction for an area on the basis of the rate of compaction measured at a nearby extensometer.

\section{Summary}

Groundwater withdrawn from the Chicot, Evangeline, and Jasper aquifers has been the primary source of water for municipal supply and for commercial and industrial uses in the Houston-Galveston region, Texas, since the early 1900s. Most of the subsidence in the Houston-Galveston region has occurred as a direct result of groundwater withdrawals for municipal supply, industrial use, and irrigation that depressured and dewatered the Chicot and Evangeline aquifers, thereby causing compaction of the clay layers of the aquifer sediments. By 1979, as much as $10 \mathrm{ft}$ of subsidence had occurred in the Houston-Galveston region, and approximately $3,200 \mathrm{mi}^{2}$ of the $11,000-\mathrm{mi}^{2}$ geographic area had subsided more than $1 \mathrm{ft}$. To address the issue of subsidence and subsequent increased flooding, the Texas State Legislature in 1975 authorized the establishment of the Harris-Galveston Subsidence District to regulate and reduce groundwater withdrawals in Harris and Galveston Counties. The Fort Bend Subsidence District subsequently was established in 1989 to regulate groundwater withdrawals in Fort Bend County and the Lone Star Groundwater Conservation District in 2001 to regulate groundwater withdrawals in Montgomery County. This report-prepared by the U.S. Geological Survey in cooperation with the HarrisGalveston Subsidence District, City of Houston, Fort Bend Subsidence District, and Lone Star Groundwater Conservation District - is one in an annual series of reports depicting water-level altitudes and water-level changes in the Chicot, Evangeline, and Jasper aquifers and compaction in the Chicot and Evangeline aquifers in the Houston-Galveston region.

The report contains maps showing 2011 water-level altitudes for the Chicot, Evangeline, and Jasper aquifers; maps showing 1-year (2010-11) water-level-altitude changes for each aquifer; maps showing 5-year (2006-11) water-levelaltitude changes for each aquifer; maps showing long-term (1990-2011 and 1977-2011) water-level-altitude changes for the Chicot and Evangeline aquifers; a map showing long-term (2000-11) water-level-altitude change for the Jasper aquifer; a map showing locations of borehole extensometer sites; and graphs showing measured compaction of subsurface material at the extensometers from 1973, or later, through 2010. Tables listing the data used to construct each aquifer-data map and the compaction graphs are included. 
Water levels in the Chicot, Evangeline, and Jasper aquifers were measured during December 2010-February 2011 (water levels usually are higher in winter compared to the rest of the year). Water-level measurements from 178 wells were used to construct the 2011 water-level-altitude map of the Chicot aquifer; contours ranged from $200 \mathrm{ft}$ below the North American Vertical Datum of 1988 (NAVD 88, hereinafter, datum) in a small area in southwestern Harris County to $200 \mathrm{ft}$ above datum in central to southwestern Montgomery County. Water-level-altitude changes in the Chicot aquifer for 2010-11 ranged from a 40-ft decline to a 33 -ft rise, for 2006-11 ranged from a 10-ft decline to a $80-\mathrm{ft}$ rise, for 1990-2011 ranged from a 140-ft decline to an 100-ft rise, and for 1977-2011 ranged from a 120-ft decline to a 200 -ft rise. Water-level measurements from 349 wells were used to construct the 2011 water-level-altitude contours of the Evangeline aquifer; contours ranged from $300 \mathrm{ft}$ below datum in north-central Harris County to $200 \mathrm{ft}$ above datum at the intersecting borders of Waller, Montgomery, and Grimes Counties. Water-level-altitude changes in the Evangeline aquifer for $2010-11$ ranged from a $43-\mathrm{ft}$ decline to a $73-\mathrm{ft}$ rise, for 2006-11 ranged from an $40-\mathrm{ft}$ decline to a $160-\mathrm{ft}$ rise, for 1990-2011 ranged from a $200-\mathrm{ft}$ decline to a $240-\mathrm{ft}$ rise, and for 1977-2011 ranged from a 340-ft decline to a 260 -ft rise. Water-level measurements from 106 wells were used to construct the 2011 water-level-altitude contours of the Jasper aquifer; contours ranged from $200 \mathrm{ft}$ below datum in south-central Montgomery County to $250 \mathrm{ft}$ above datum in east-central Grimes County. Water-level-altitude changes in the Jasper aquifer for 2010-11 ranged from a 45-ft decline to a 29 -ft rise, for 2006-11 ranged from a $90-\mathrm{ft}$ decline to a 10-foot rise, and for 2000-11 ranged from a 190-ft decline to no change. For the Chicot and Evangeline aquifers, depictions of long-term water-level change (1977-2011) show areas of decline in northern, northwestern, and southwestern Harris County and a broad area of water-level rise in southeastern Harris and northern Galveston Counties. For the Jasper aquifer, depictions of long-term water-level change (2000-11) show that water-level declines have occurred in most of Montgomery County and north-central Harris County.

Compaction of subsurface materials (mostly in the clay layers) composing the Chicot and Evangeline aquifers was recorded continuously at the 13 borehole extensometers at 11 sites. The rates of compaction measured by each extensometer were initially highest in the years preceding installation. When reductions in groundwater withdrawals were required following the creation of the Harris-Galveston Subsidence District in 1975, the rate of groundwater withdrawal began to decrease along with the rate of clay compaction. Coincident with the curtailment of groundwater withdrawals, the water levels of the aquifers began to rise. Water levels in the Chicot and Evangeline aquifers have risen as much as 200 and 260 $\mathrm{ft}$, respectively, as shown on the 1977-2011 long-term-change maps. For the period of record beginning in 1973, or later, and ending in December 2010, cumulative clay compaction at 12 of the 13 borehole extensometers in the Chicot and Evangeline aquifers ranged from $0.100 \mathrm{ft}$ at the Texas City-Moses Lake extensometer (KH-64-33-920) to $3.544 \mathrm{ft}$ at the Addicks extensometer (LJ-65-12-726). The rate of compaction varies from site to site because of differences in groundwater withdrawals near each site and differences among sites in the clay-to-sand ratio of the subsurface materials. Therefore, it is not possible to extrapolate or infer a rate of clay compaction for an area on the basis of the rate of compaction measured at a nearby extensometer.

\section{References Cited}

Allen, A.S., 1969, Geologic settings of subsidence, in Varnes, D.J., and Kiersch, G., eds., Reviews in engineering geology: Geological Society of America, v. 2, p. 305-342.

Baker, E.T., Jr., 1979, Stratigraphic and hydrogeologic framework of part of the Coastal Plain of Texas: Texas Department of Water Resources Report 236, 43 p.

Baker, E.T., Jr., 1986, Hydrology of the Jasper aquifer in the southeast Texas Coastal Plain: Texas Water Development Board Report 295, 64 p.

Barbie, D.L., Coplin, L.S., and Locke, G.L., 1991, Approximate altitude of water levels in wells in the Chicot and Evangeline aquifers in the Houston area, Texas, January-February 1990: U.S. Geological Survey Open-File Report 91-240, 2 sheets.

Carr, J.E., Meyer, W.R., Sandeen, W.M., and McLane, I.R., 1985, Digital models for simulation of ground-water hydrology of the Chicot and Evangeline aquifers along the Gulf Coast of Texas: Texas Department of Water Resources Report 289, $101 \mathrm{p}$.

Chowdhury, A.H., and Turco, M.J., 2006, Geology of the Gulf Coast aquifer, Texas, in Mace, R.E., Davidson, S.C., Angle, E.S., and Mullican, W.F., eds., Aquifers of the Gulf Coast of Texas: Texas Water Development Board Report 365, chap. 2, p. 23-50, accessed March 7, 2011, at http://www. twdb.state.tx.us/publications/reports/GroundWaterReports/ GWReports/R365/ch02-Geology.pdf.

Coplin, L.S., 2001, Water-level altitudes in wells completed in the Jasper aquifer, greater Houston area, Texas, spring 2000: U.S. Geological Survey Open-File Report 2001-147, 1 sheet.

Coplin, L.S., and Galloway, Devin, 1999, Houston-Galveston, Texas-Managing coastal subsidence, in Galloway, Devin, Jones, D.R., and Ingebritsen, S.E., eds., Land subsidence in the United States: U.S. Geological Survey Circular 1182, p. 35-48. 
Fort Bend Subsidence District, 2009, Fort Bend Subsidence District 2003 regulatory plan [amended 2007, 2009]: 14 p., accessed March 7, 2011, at http://www.fbsubsidence.org/ assets/pdf/FBRegPlan.pdf.

Gabrysch, R.K., 1979, Approximate altitude of water levels in wells in the Chicot and Evangeline aquifers in the Houston area, Texas, spring 1977 and spring 1978: U.S. Geological Survey Open-File Report 79-334, 4 sheets.

Gabrysch, R.K., 1984, Ground-water withdrawals and landsurface subsidence in the Houston Galveston region, Texas, 1906-80: Texas Department of Water Resources Report 287, 64 p.

Gabrysch, R.K., and Bonnet, C.W., 1975, Land-surface subsidence in the Houston-Galveston region, Texas: Texas Water Development Board Report 188, 19 p.

Galloway, Devin, Jones, D.R., and Ingebritsen, S.E., eds., 1999, Land subsidence in the United States:

U.S. Geological Survey Circular 1182, 177 p.

Harris County Flood Control District, Tropical Storm Allison Recovery Project, 2002, Harris County, Texas lidar, digital data: Charleston, S.C., National Oceanic Atmospheric Administration Coastal Services Center, accessed, May 20, 2011, at http://www.csc.noaa.gov/crs/tcm/ldartdat/ metatemplate/tx2001_harris_template.html.

Harris-Galveston Subsidence District, 2010, District regulatory plan 1999 [amended 2001, 2010]: 16 p., accessed March 7, 2011, at http://www.hgsubsidence.org/assets/ pdfdocuments/HGRegPlan.pdf.

Holzer, T.L., and Bluntzer, R.L., 1984, Land subsidence near oil and gas fields, Houston, Texas: Ground Water, v. 22, p. $450-459$.

Kasmarek, M.C., 1997, Water-level altitudes in wells completed in the Chicot and Evangeline aquifers, Fort Bend County and adjacent areas, Texas, January-February 1990: U.S. Geological Survey Open-File Report 97-784, 2 sheets.

Kasmarek, M.C., Gabrysch, R.K., and Johnson, M.R., 2010, Estimated land-surface subsidence in Harris, Texas, 1915-17 to 2001: U.S. Geological Survey Scientific Investigations Map 3097, 2 sheets.

Kasmarek, M.C., and Houston, N.A., 2007, Water-level altitudes 2007 and water-level changes in the Chicot, Evangeline, and Jasper aquifers and compaction 1973-2006 in the Chicot and Evangeline aquifers, Houston-Galveston region, Texas: U.S. Geological Survey Scientific Investigations Map 2968, 159 p., 18 sheets.
Kasmarek, M.C., Houston, N.A., and Brown, D.W., 2006, Water-level altitudes 2006 and water-level changes in the Chicot, Evangeline, and Jasper aquifers and compaction 1973-2005 in the Chicot and Evangeline aquifers, Houston-Galveston region, Texas: U.S. Geological Survey Open-File Report 2006-1079, 15 sheets.

Kasmarek, M.C., Johnson, M.R., and Ramage, J.K., 2010, Water-level altitudes 2010 and water-level changes in the Chicot, Evangeline, and Jasper aquifers and compaction 1973-2009 in the Chicot and Evangeline aquifers, HoustonGalveston region, Texas: U.S. Geological Survey Scientific Investigations Map 3138, 17 p., 16 sheets, 1 appendix.

Kasmarek, M.C., and Lanning-Rush, Jennifer, 2004, Waterlevel altitudes 2004 and water-level changes in the Chicot, Evangeline, and Jasper aquifers and compaction 1973-2003 in the Chicot and Evangeline aquifers, Houston-Galveston region, Texas: U.S. Geological Survey Open-File Report 2004-1184, 13 sheets.

Kasmarek, M.C., and Robinson, J.L., 2004, Hydrogeology and simulation of ground-water flow and land-surface subsidence in the northern part of the Gulf Coast aquifer system, Texas: U.S. Geological Survey Scientific Investigations Report 2004-5102, 111 p.

Lambeck, Kurt, Esat, T.M., and Potter, Emma-Kate, 2002, Links between climate and sea levels for the past three million years: Nature, v. 419, no. 6903, p. 199-206, accessed March 7, 2011, at http://www.nature.com/nature/ journal/v419/n6903/index.html.

Lone Star Groundwater Conservation District, 2011, Lone Star Groundwater Conservation District rules and bylaws: accessed March 7, 2011, at http://www.lonestargcd.org/ management_plan.html.

National Oceanic and Atmospheric Administration, 2008, The elements of geodesy-The vertical datum: accessed March 7, 2011, at http://oceanservice.noaa.gov/education/kits/ geodesy/geo06_vertdatum.html.

Popkin, B.P., 1971, Ground-water resources of Montgomery County, Texas: Texas Water Development Board Report 136, 143 p.

Pratt, W.E., and Johnson, D.W., 1926, Local subsidence of the Goose Creek oil field (Texas): Journal of Geology, v. 34, no. 7 , p. 577-590.

Trahan, D.B., 1982, Monitoring local subsidence in areas of potential geopressured fluid withdrawal, southwestern Louisiana: Gulf Coast Association of Geological Societies Transactions, v. 32, p. 231-236. 
University of Texas, Bureau of Economic Geology, 1968, Geologic atlas of Texas, Beaumont sheet: Austin, scale 1:250,000.

University of Texas, Bureau of Economic Geology, 1974, Geologic atlas of Texas, Austin sheet: Austin, scale 1:250,000.

U.S. Army Corps of Engineers, 2006, Corpscon version 6: Topographic Engineering Center, Survey Engineering and Mapping Center of Expertise, accessed March 7, 2011, at http://crunch.tec.army.mil/software/corpscon/corpscon.html.

U.S. Geological Survey, 2011, National Water Information System - Web interface - USGS water data for Texas: U.S. Geological Survey database, accessed March 7, 2011, at http://waterdata.usgs.gov/tx/nwis/nwis.

Wesselman, J.B., 1972, Ground-water resources of Fort Bend County, Texas: Texas Water Development Board Report 155, 176 p.
Winslow, A.G., and Doyle, W.W., 1954, Land-surface subsidence and its relation to the withdrawal of ground water in the Houston-Galveston region, Texas: Economic Geology, v. 40, no. 4, p. 413-422, accessed March 7, 2011, at http://econgeol.geoscienceworld.org/cgi/reprint/49/4/413.

Winslow, A.G., and Wood, L.A., 1959, Relation of land subsidence to ground-water withdrawals in the upper Gulf Coast region, Texas: Mining Engineering, p. 1,030-1,034, accessed March 7, 2011, at http://www.aimehq.org/search/ docs/Volume\%20214/214-52.pdf.

Worboys, M.F., 1995, GIS-A computer science perspective: London, Taylor and Francis, 376 p. 

I SBN 978-1-4113-3233- 1 